\title{
DISEASE PROGRESSION POTATOES (SOLANUM TUBEROSUM L.) DURING STORAGE DEPENDING ON THE TERM OF PLANTING AND PROCESSING DRUGS BIOLOGICAL AND CHEMICAL ORIENTATION IN WESTERN POLISSYA
}

\author{
Boroday V. V. ${ }^{1}$, Danilkova T. V. ${ }^{2,}$ Koltunov V. A. ${ }^{3}$ \\ ${ }^{1}$ National University of Life and Environmental Sciences of Ukraine, ul. Heroes of \\ Defense, 13, Kiev, 03041, Kiev \\ E-mail: veraboro@gmail.com \\ ${ }^{2}$ State Phytosanitary Inspection of Lviv Oblast, ul. Vitovskogo, 18, 79011, m. Lviv \\ ${ }^{3}$ Kyiv National Trade and Economic University str. Kyoto, 19 02156, m. Kyiv
}

Application of biological preparations (Planriz, Fitotsid, Diazofit and Fosfoenterin) and chemicals (MC Ridomil Gold 68WG) in the conditions of Western Polissya has reduced the pathogens infection in 1.6-2.2 times at treatment of tubers prior to planting, plants during budding and flowering stages, as well as before storage. The least general disease development was observed in variants with Planriz (2.0-2.5 l/t), and the composition of biological preparation Planriz, Diazofit and Fosfoenterin (2.0-2.5 + 0.2 + 0.2 l/t). Among the total number of diseases the wet bacterial rot was 14.3-30.0\%, Phoma exigua - 6.7-16.3\%, Fusarium spp. - 62.5-71.1\%. The development of Fusarium spp. has increased in 1.6 times at the end of storage period, Phoma exigua - in 4 times. The level of bacterial rot development had remained unchanged for the tubers of the Lileya cultivar planted in mid-May. The planting dates had almost no influence on the prevalence of disease at storage of the potatoes of Skarbnitsa cultivar.

Keywords: Solanum tuberosum L., planting dates, microbiological preparatios, diseases, Pectobacterium carotovorum, Phoma exigua Desm. , Fusarium spp., storage

Potatoes yield and marketability, as well as the intensity of the disease development on tubers during the storage time are directly dependent on the level of potatoes diseases during the growing season [2, 6, 7]. Measures used for reduction of the diseases development during the growing season, allow receiving more healthy tubers with minimal susceptibility to the pathogens and their development during the storage time. One of the promising agricultural means in the technologies of potatoes cultivation is the use of microbial preparations. Treatment of potatos with biological preparations corrects the microbial composition on the in surface of plant roots and within the root zone, thus ensuring less pathogens development and promoting plant growth [3].

Highly virulent strains of bacteria Pseudomonas fluorescens, Rhizobium radiobacter, Bacillus subtilis and Enterobacter nimipressuralis are commonly used in agricultural biotechnology as the basis for preparations Planriz, Fitotsid, Diazofit and Fosfoenteryn (FMB), developed for plants protection against diseases of different etiologies $[8,11,12]$. Microbial preparations do not only protect plants 
from pathogenic microorganisms, but also improve phosphorus nutrition of plants, mobilizing phosphate from insoluble organic and inorganic phosphorus, synthesize growth stimulating substances, promotes seeds germination and development of seedlings $[3,11]$.

The efficiency of Planriz, Fitotsid, Diazofit and FMB was investigated for different crops in various climatic zones, but mostly during the vegetative period of plants. Available literature data is insufficient for reliable and reasonable conclusions of efficient preparations in order to receive for potatoes with high output qualities, including storage characteristics. Overall, the technology of production of high-quality potato planting material as well as storage means do still require improvement decisions.

Materials and methods. Methods of field research and potatoes storage means were common for the region $[1,10,12]$. Three biological preparations Planriz (biological agent Pseudomonas fluorescence AR-33), Diazofit (biological agent - Agrobacterium radiobacter 204), FMB (biological agent - phosphorous mobilizing bacteria Enterobacter nimipressuralis 32-3) manufactured in biological laboratory of State Inspection for Plant Protection in the Lviv region were used. Potatoes (early-maturing variety Skarnytsa and middle-maturing variety Lileya), due to the rainy weather conditions in Lviv region in spring were planted in the third decade of April, the second and the third decades of May. Biological preparations were used for tubers treatment before planting, and later - as foliars, during budding and flowering stages, and tuber treatment before storage. As biological control the biological preparation Fitotsid was used. As chemical control - we used the Rydomil Gold MC. The crop was harvested from third week of August to the second week of September and kept for $7-8$ months (before planting) in storage facilities without artificial cooling.

Results and discussion. One of the main factors limiting high potatoes yields in all agro-climatic zones of Ukraine is the insufficient quantity of planting material, due the its primarily lower production performed in favorable conditions with low infectious background, absence of technological requirements of the original production of elite planting material [6]. As a result, a large number of commodity producers use potato planting tubers of low quality affected with diseases. Dry rot agents: bacterial - Pectobacterium carotovorum subsp. carotovorum (Jones 1901) Hauben et al. 1999 emend. Gardan et al. 2003, phomosis - Phoma exigua Desm. and fusarium blight - Fusarium spp. cause significant losses during the potatoes storage $[2,4,5,9]$.

According to our research, an average of $4-11 \%$ of non-standard potatoes are put into long-term storage [6]. The standard batch usually has some of the tubers with various tolerances (mechanically damaged tubers or tubers affected by pathogens, etc.) - to $6.12 \%$. Among the highest percentage of non-standard parts are infected tubers (normal scab, Fusarium and phomosis rot can constitute $3.2-$ $6.6 \%$ ). This, in turn, contributes to the reduction of storage capacities and quality of potatoes. According to our data, the batch with the highest number of tubers affected at the beginning of storage, in March has $25.4 \%$ of infected tubers compared with other tubers: $10.4-15.6 \%$. Use of infected tubers for planting 
results in dropping out of up to $24 \%$ of plants, that lag behind in development (10$40 \%$ ), which in turn had caused yield shortfall (14\%).

Upon the use of biological (Planriz, Fitotsid, Diazofit and FMB) and chemical (RydomilHold 68WG MC) preparations for tubers treatment before planting as well as plants treatment during budding and flowering stages, and tubers treatment before storing them reduction of tubers infection with pathogens in 1.9-2.2 times for potatoes of Lileya variety and 1.6 times in Skarbnitsya variety was noticed (Table 1 and 2).

Among the total number of diseases of potatoes of Lileya variety of the first planting term the level of bacterial rot was around $23.3 \%$, while the part pf phomosis ort $-6.7 \%$, and Fusarium dry rot $-70.0 \%$. In potatoes from the second planting term (second decade of May) the level of Fusarium spp. development had grew on 1.6 times, phomosis rot -4 times. Tubers infection with bacterial rot remained unchanged. The Fusarium dry rot had was also the most common observed disease for Skarbnitsya variety of first and second planting terms $62.5 \%$. However, the planting dates have not affected the prevalence of disease during storage time $(4.0 \%$ and $3.8 \%)$, although their growth was lower than the level of bacterial rot (planting in the third decade of April $-1.2 \%$ vs. $0.7 \%$ in the second decade - early May). Thus when selecting protective means against the diseases prior to the storage time the genotype peculiarities of each variety towards their resistance to pathogens should be taken into the account.

The smallest overall development of diseases compared to the absolute control (no treatment), variants with biological control (Fitotsid) and chemical control (Rydomil Gold) was observed upon the application of Planriz at concentration 2.0-2.5 $1 / \mathrm{t}$ and composition of biological preparations Planriz, Diazofit and FMB $(2.0-2.5+0.2+0.2 \mathrm{l} / \mathrm{t})$. Combined use of Rydomil Gold with Planrizu compared with to the treatment of tubers of Lileya variety with the fungicide only had indicated that only at the second planting term the rates had slightly declined from $5.7 \%$ to $5.1 \%$. The difference was more significant in variants with the Skarbnyts variety - from 5.4 to $4.0 \%$ for planting in the third decade of April, and from 5.6 to 3.3\% - in the second decade of May.

Consequently, the use of microbial preparations had contributed to a higher quality spring planting material.

In modern conditions the increase of crops yields, including potatoes, it is important to achieve high farming culture, widespread introduction of advanced technologies with minimal use of agrochemicals. Potatoes cultivation for purposes has strong hygiene requirements. Application of biological preparations (against a background of high farming) can save a crop of vegetables and potatoes and to provide a quality product, thus, significantly reduce and sometimes completely eliminate the use of chemicals.

Pre-planting treatment of tubers and subsequent plants spraying during the growing season with the suspensions of biological preparations promote the reduction of the population density of pathogens in the soil, on new tubers and increase plants resistance to diseases. 
Table 1. Tubers infection during storage time depending on their treatment with chemical and biological preparations

(2009-2012, Lileya variety, West Polissya region), \%

\begin{tabular}{|c|c|c|c|c|c|c|c|c|}
\hline \multirow{3}{*}{ Variants } & \multicolumn{4}{|c|}{$1^{\text {st }}$ planting term } & \multicolumn{4}{|c|}{$2^{\text {nd }}$ planting term } \\
\hline & \multicolumn{4}{|c|}{ Disease type } & \multicolumn{4}{|c|}{ Disease type } \\
\hline & $\mathrm{BWR}^{*}$ & $\mathrm{PR}^{*}$ & FDR $^{*}$ & Overall & $\mathrm{BWR}^{*}$ & $\mathrm{PR}^{*}$ & FDR $^{*}$ & Overall \\
\hline $\begin{array}{l}\text { Without treatment } \\
\text { (control) }\end{array}$ & 2,5 & 0,5 & 3,7 & 6,7 & 3,1 & 0,8 & 5,4 & 9,3 \\
\hline Fitotsid, $11 / \mathrm{t}$ & 0,7 & 0,0 & 2,6 & 3,3 & 0,6 & 0,4 & 4,7 & 5,7 \\
\hline $\begin{array}{l}\text { Rydomil Gold MC } \\
68 \mathrm{WG}\end{array}$ & 0,4 & 0,1 & 2,0 & 2,6 & 1,6 & 1,0 & 3,1 & 5,7 \\
\hline Planriz $(1,01 / \mathrm{t})$ & 0,2 & 0,1 & 2,6 & 2,9 & 1,5 & 0,1 & 3,4 & 5,1 \\
\hline Planriz $(1,5$ 1/t $)$ & 1,1 & 0,1 & 2,1 & 3,3 & 0,0 & 1,3 & 3,4 & 4,7 \\
\hline Planriz $(2,0$ 1/t $)$ & 0,8 & 0,2 & 1,6 & 2,6 & 0,3 & 0,0 & 2,6 & 2,9 \\
\hline Planriz $(2,5$ 1/t $)$ & 0,9 & 0,4 & 1,7 & 3,1 & 0,1 & 1,0 & 3,3 & 4,4 \\
\hline $\begin{array}{l}\text { Planriz + Diasofit } \\
+ \text { PMB }(1,0+0,2+ \\
0,21 / t)\end{array}$ & 0,2 & 0,1 & 2,0 & 2,3 & 0,4 & 1,0 & 2,1 & 3,5 \\
\hline $\begin{array}{l}\text { Planriz + Diasofit } \\
+ \text { PMB }(1,5+0,2+ \\
0,21 / t)\end{array}$ & 0,5 & 0,3 & 1,6 & 2,4 & 0,0 & 0,7 & 3,3 & 4,1 \\
\hline $\begin{array}{l}\text { Planriz + Diasofit } \\
+ \text { PMB }(2,0+0,2+ \\
0,21 / t)\end{array}$ & 0,5 & 0,0 & 1,8 & 2,4 & 0,0 & 1,1 & 2,8 & 3,9 \\
\hline $\begin{array}{l}\text { Planris + Diasofit }+ \\
\operatorname{PMB}(2,5+0,2+ \\
0,21 / t)\end{array}$ & 0,2 & 0,0 & 1,5 & 1,7 & 0,2 & 0,9 & 3,3 & 4,4 \\
\hline $\begin{array}{l}\text { Planriz + Rydomil } \\
\text { Gold } 68 \text { WG MC } \\
(2,0+2,51 / \mathrm{t})\end{array}$ & 0,8 & 0,7 & 1,3 & 2,8 & 0,6 & 1,6 & 2,9 & 5,1 \\
\hline $\mathrm{LSD}_{05}$ & & & & 1,3 & & & & 1,2 \\
\hline Average & 0,7 & 0,2 & 2,1 & 3,0 & 0,7 & 0,8 & 3,4 & 4,9 \\
\hline
\end{tabular}

* MBG - bacterial wet rot, PR - phomosis rot, PFE - Fusarium dry rot

Thus, application of biological (Planriz, Fitotsid, Diazofit and FMB) and chemical (RydomilHold 68WG MC) preparations in Western Polissya for the tubers treatment before planting, followed by the plants treatment during budding and flowering stages and tubers treatment before storage had ensured the reduction of pathogens infections in 1.6-2.2 times. The lowest overall development of disease compared with control (no treatment), biological control (Fitotsid) and chemical control (Rydomil Gold) was observed in the variant with Planriz application at concentration 2.0-2.5 $1 / \mathrm{t}$ and with the composition of biological preparations Planriz, Diazofit and FMB $(2.0-2.5+0.2+0.21 / \mathrm{t})$. Among the total number of diseases the part of bacterial wet rot was $14.3-30.0 \%$, phomosis rot - 
$6.7-16.3 \%$ Fusarium dry rot $-62.5-71.1 \%$. For the second planting term of Lileya variety (second decade of May) the development of Fusarium spp. was higher in 1.6 times and phomosis rot - in 4 times. For Skarbnitsya variety the planting term had almost no influence on the prevalence of disease development during storage time $(4.0 \%$ and $3.8 \%)$, although the growth of bacterial rot was slightly lower. To improve the potato tubers preservation it is required to reduce the tubers contamination with pathogens throughout the complete process of potatoes cultivation by treatment of potato tubers before planting with biological preparations, and applying them throughout the growing season and prior to the storage.

Table 2. Disease infection of tubers during storage comparing their treatment with chemicals and biological preparations (2009-2012, Skarbnitsya variety, Western Polissya, \%

\begin{tabular}{|c|c|c|c|c|c|c|c|c|}
\hline \multirow{3}{*}{ Variants } & \multicolumn{4}{|c|}{$1^{\text {st }}$ planting term } & \multicolumn{4}{|c|}{$2^{\text {nd }}$ planting term } \\
\hline & \multicolumn{4}{|c|}{ Disease type } & \multicolumn{4}{|c|}{ Disease type } \\
\hline & $\mathrm{BWR}^{*}$ & $\mathrm{PR}^{*}$ & FDR & overall $^{*}$ & $\mathrm{BWR}^{*}$ & $\mathrm{PR}^{*}$ & FDR & overall $^{*}$ \\
\hline $\begin{array}{l}\text { Without treatment } \\
\text { (control) }\end{array}$ & 2,7 & 0,2 & 3,4 & 6,4 & 1,8 & 0,5 & 3,9 & 6,2 \\
\hline Fitotsid, 1 1/t & 0,5 & 0,2 & 2,8 & 3,5 & 0,0 & 0,5 & 3,6 & 4,1 \\
\hline $\begin{array}{l}\text { Rydomil Gold MC } \\
68 \mathrm{WG}\end{array}$ & 2,1 & 0,4 & 2,9 & 5,4 & 1,8 & 1,0 & 2,8 & 5,6 \\
\hline Planriz $(1,01 / \mathrm{t})$ & 1,8 & 0,1 & 2,1 & 4,1 & 1,0 & 0,1 & 3,3 & 4,4 \\
\hline Planriz $(1,51 / t)$ & 2,2 & 0,2 & 2,2 & 4,6 & 0,8 & 0,9 & 3,0 & 4,7 \\
\hline Planriz $(2,0$ l/t $)$ & 0,7 & 0,3 & 2,7 & 3,7 & 0,9 & 0,1 & 2,3 & 3,2 \\
\hline Planriz $(2,5$ l/t $)$ & 0,6 & 0,3 & 1,9 & 2,9 & 0,4 & 0,5 & 2,2 & 3,2 \\
\hline $\begin{array}{l}\text { Planriz + Diasofit }+ \\
\text { PMB }(1,0+0,2+ \\
0,21 / t)\end{array}$ & 0,9 & 0,4 & 1,7 & 3,0 & 0,2 & 0,2 & 2,6 & 3,1 \\
\hline $\begin{array}{l}\text { Planriz + Diasofit + } \\
\text { PMB }(1,5+0,2+ \\
0,21 / t)\end{array}$ & 1,4 & 0,6 & 3,3 & 5,3 & 0,5 & 0,3 & 2,6 & 3,3 \\
\hline $\begin{array}{l}\text { Planriz + Diasofit }+ \\
\text { PMB }(2,0+0,2+ \\
0,2 \text { 1/t })\end{array}$ & 0,1 & 0,0 & 2,2 & 2,3 & 0,3 & 0,1 & 2,0 & 2,4 \\
\hline $\begin{array}{l}\text { Planris + Diasofit }+ \\
\operatorname{PMB}(2,5+0,2+0,2 \\
1 / \mathrm{t})\end{array}$ & 0,8 & 0,0 & 2,3 & 3,0 & 0,2 & 0,2 & 2,1 & 2,5 \\
\hline $\begin{array}{l}\text { Planriz + Rydomil } \\
\text { Gold } 68 \text { WG MC } \\
(2,0+2,51 / \mathrm{t})\end{array}$ & 0,7 & 0,3 & 2,5 & 3,5 & 0,5 & 0,2 & 2,6 & 3,3 \\
\hline $\mathrm{HIP}_{05}$ & & & & 1,2 & & & & 1,1 \\
\hline Середнє & 1,2 & 0,3 & 2,5 & 4,0 & 0,7 & 0,4 & 2,7 & 3,8 \\
\hline
\end{tabular}

*BWR - bacterial wet rot, PR - phomosis rot, FDR - Fusarium dry rot 